\title{
Trp-574-Leu mutation in wild mustard (Sinapis arvensis L.) as a result of als inhibiting herbicide applications
}

\author{
Bahadir Sin ${ }^{\text {Corresp., } 1}$, İzzet Kadıoglu ${ }^{1}$ \\ ${ }^{1}$ Department of Plant Pathology, Faculty of Agriculture, Tokat Gaziosmanpasa University, Tokat, Turkey \\ Corresponding Author: Bahadir Sin \\ Email address: bahadir.sin@gop.edu.tr
}

Wheat is one of the most important crops grown all around the world. Weeds cause significant yield loss and damage to wheat and their control is generally based on herbicide application. Regular use leads to herbicide resistance in weeds. This study aims to reveal molecular detection of Sinapis arvensis resistance mutation against ALS inhibiting herbicides. For this purpose, survey studies have been carried out in wheat growing areas in Amasya, Çorum, Tokat, and Yozgat provinces and wild mustard seeds have been collected from 310 different fields. According to bioassay tests with tribenuronmethyl, 13 of these populations, have not been affected by the registered dose of herbicide. When survived populations were subjected to dose-effect study and herbicides were applied at 26-fold, the highest and lowest resistance coefficients were determined as 7.2 (A-007) and 1.02 (T-034) respectively. In addition, B domain region from ALS gene was amplified and analyzed in molecular studies to determine point mutation in wild mustard against ALS herbicides. The PCR products were sequenced and target-site mutation to Leucine was observed at Trp-574 amino acide. In the study, point mutation in Trp-574 amino acide and Trp-574 Leu mutation in Sinapis arvensis have been detected for the first time in Turkey. 
4

\section{Trp-574-Leu mutation in wild mustard (Sinapis arvensis 1.) is a result of ALS-inhibiting}

\section{herbicidal applications}

Bahadır ŞİN ${ }^{1}$, İzzet KADIOĞLU ${ }^{1}$

${ }^{1}$ Department of Plant Pathology, Faculty of Agriculture, Tokat Gaziosmanpasa University, 60200, Tokat, Turkey

Corresponding Author:

Bahadır ŞİN ${ }^{1}$

Department of Plant Pathology, Faculty of Agriculture, Tokat Gaziosmanpasa University, 60200, Tokat, Turkey Email address: bahadir.sin@gop.edu.tr

\section{Abstract}

Wheat is one of the most important crops grown throughout the world. Weeds cause significant yield losses and damage to wheat and are generally controlled using an herbicide. The regular use of herbicides may lead weeds to become resistant. We sought to determine the molecular mechanism for the resistance mutation in Sinapis arvensis against ALS-inhibiting herbicides. Surveys were conducted in the wheat-growing areas of the Amasya, Çorum, Tokat, and Yozgat provinces and wild mustard seeds were collected from 310 fields. Thirteen of these wheat populations were not affected by the registered doses of herbicides according to bioassay tests with tribenuron-methyl. Populations that survived the application of the herbicide were subjected to a dose-effect study and herbicides were applied at 16-fold, and the highest and lowest resistance coefficients were determined to be 7.2 (A-007) and 1.02 (T-034), respectively. The B domain from the ALS gene was amplified and analyzed in molecular studies to determine the point mutation in wild mustard against ALS herbicides. The PCR products were sequenced and leucine's target-site mutation was located in the Trp-574 amino acid. We discovered the point mutation in the Trp-574 amino acid and the Trp-574 Leu mutation in Sinapis arvensis for the first time in Turkey. 


\section{Introduction}

37

38

39

40

41

42

43

44

45

46

47

48

49

50

51

52

53

54

55

56

57

58

59

60

61

62

63

64

65

66

67
Wheat is an important, high-fiber food consumed daily by human beings. Approximately $21 \%$ of one's daily caloric needs are supplied by wheat products (Shiferaw et al., 2013). Cereal grains provide $52 \%$ of the total protein and $50 \%$ of the total carbohydrate and energy worldwide; in Turkey specifically they account for $60 \%$ and $80 \%$, respectively. Wheat consumption is higher in poor countries (Atak, 2004; Aydın et al., 2005). Food demand parallels rapid population growth and results in the enlargement of wheat production areas and, consequentially, an increased yield. The goals of production are to produce a higher quality product and yield from areas with restricted agricultural capacity around the world.

The reduction in yield and quality are major problems in cultivated areas. Cultivated crops are impacted by ecological conditions, stress factors, and plant pests (insects, spider mites, nematodes, diseases, and weeds) and may encounter significant yield losses. Weeds, pests, and pathogens yield worldwide crop losses estimated to be $34 \%, 18 \%$, and 16\%, respectively. Overall economic crop losses due to weeds have cost 75.6 billion U.S. dollars, which is equivalent to 2.5-2.7 billion dollars in Australia and five billion dollars in the USA (Schneider, 1985; Combellak, 1987; Oerke et al., 1994; Jabran et al., 2015).

Weeds are a major cause of yield loss in wheat. Weeds are capable of germinating before wheat typically emerges and grows, competing with the crop plant for space, nutrients, water, and sunlight (Özer et al., 2003; Oerke and Dahne, 2004). Weeds may cause critical damage to wheat approximately 30-60 days after sowing (Marwat et al., 2013). Apart from these direct and indirect damages, weeds may also reduce the wheat quality and seed value by mixing with their seeds to products and cause color, taste, and odor deterioration when they are milled with flour. Several pests and disease agents hosted by weeds may cause secondary infections (Özer et al., 2003; Bülbül and Aksoy, 2005; Anonymous, 2008; Güncan and Karaca, 2014).

The average yield loss to wheat is estimated to be $15.6 \%$, despite weed control measures (Oerke et al., 1999; Oerke, 2006; Güncan and Karaca, 2014). Yield loss reaches up to 100\% in non-controlled fields and yield loss is reported to be $20-35 \%$ in Turkey (Güncan, 1972; Anonymous, 2008). Wheat is not hoed and weed control is typically conducted using chemicals, the specific amount of phytotoxic active substances depending on the type of herbicide. These chemicals cause death or reduce growth of weeds by inhibiting certain reactions such as amino acid synthesis, photosynthesis, and lipid biosynthesis (Ghorbani et al., 2005). In 2020, 3.5 million

Peer) reviewing PDF | (2020:11:55641:3:0:NEW 3 Apr 2021) 
68 tons of pesticides were used across the globe. Herbicides constitute approximately $50 \%$ of the 69 pesticides used in 2010 (Sharma et al., 2019; FAO, 2020).

70

71

72

73

74

75

76

77

78

79

80

81

82

83

84

85

86

87

88

89

90

91

92

93

94

95

96

97

98

Herbicide application increases daily and herbicide resistance may occur with improper use. Herbicide resistance has developed in 262 plants around the world (152 dicotyledon, 110 monocotyledon). A total of 512 cases have been reported in 23 of 26 known herbicide groups in 92 plants in 70 countries (Corbertt and Tardif, 2006; Heap, 2014; Heap, 2020).

Resistance was confirmed for the first time in Senecio vulgaris in 1957 (Holt, 1988). ALS herbicides have been used heavily since they were commercialized in 1980 (Mallory-Smith et al., 1990). The first report of ALS resistance occurred 1982 in Lolium rigidum in Australia. However, the first case in tribenuron-methyl resistance in wild mustard was reported in canola fields in 2002 in Canada (Heap, 2020).

ALS-inhibiting herbicides play a significant role in weed control for wheat and are preferred due to their efficacy in lower doses and lower toxicity to mammals (De Prado et al., 2004). Herbicide resistance was observed in corn fields in 1983 in Sinapis arvensis against the photosystem II inhibitor (C1) group herbicide, atrazine. ALS herbicide resistance was found in winter barley, wheat, and canola, and tribenuron-methyl resistance was discovered in canola and cereals in 2002 (Ali et al., 1986; Heap et al., 1992; Debreuil et al., 1996; Morrison and Devine, 1994; Warwick et al., 2005; Heap, 2020). Eighteen cases in 15 herbicide-weed actions have been reported in Turkey. Five of those cases were resistant to ALS-inhibiting herbicides, six showed multiple resistances, and two were resistant in S. arvensis (Heap, 2020).

The continuous use of ALS herbicides promotes the rapid emergence of resistance in weeds. There are several mechanisms for the development of resistance, however target site mutation is considered to be the most important of these mechanisms (Devine and Shukla, 2001; Grassel, 2002). Herbicides cannot bind to their target site and weeds become resistant as a result of alterations in amino acids caused by mutations (Kaya-Altop et al., 2017). Mutations are seen in the amino acid locations Ala 122, Ala 205, Asp 376, Gly 654, Pro 197, Trp 574, and Ser 653 (Powles and Yu, 2010; Vencill et al., 2012). These locations may vary depending on the herbicides' active reagent.

We sought to investigate target site mutations in the ALS gene in ALS-resistant S. arvensis found in wheat fields. 
99

100

101

102

103

104

105

106

107

108

109

110

111

112

113

114

115

116

117

118

119

120

121

122

123

124

125

126

127

128

129

\section{Materials \& Methods}

\subsection{Collection of plant material}

We used wild mustard seeds collected in April-July, 2018 from wheat fields in Amasya, Tokat, Çorum, and Yozgat. There were 36, 62, 109 and 103 populations in the four provinces, respectively. We used a control population obtained from a field in Tokat where no herbicides were applied. A total of 311 populations, including the control, were collected during our field surveys (Figure 1).

\subsection{Resistance determination assay}

The level of ALS herbicide resistance of the populations was determined by a single-dose assay experiment arranged by Moss et al. (1999). All populations were treated with $10 \mathrm{~g}$ a.i. ha-1 tribenuron-methyl and were screened for 1 month. The assay test results showed that populations with less than $80 \%$ reagent efficacy were putative resistant populations and others with higher efficacy were susceptible.

\subsection{Dose-responses to tribenuron-methyl}

The undetermined populations selected from the previous resistance assay were treated with the registered dose of herbicide at one, two, four, eight and 16-fold levels. Susceptible populations were treated with $0.25\left(2.5 \mathrm{~g}\right.$ a.i. $\left.\mathrm{ha}^{-1}\right)$ and $0.5\left(5 \mathrm{~g}\right.$ a.i. ha $\left.{ }^{-1}\right)$ doses and the assay was established in $1.2 \mathrm{~kg}$ pots. The trials were conducted with four replicates with two repeats for each population and herbicide dose. Each pot was covered with polyethylene and maintained in greenhouse conditions after spraying. The length of the experiment was determined and trials were established by coinciding with the active period of wild mustard. We used a pressure-adjusted MATHABIbrand back sprayer with a fan jet nozzle under a constant pressure of three atm, and 300 liters of water per hectare was applied when plants had four to six leaves. The plants were checked regularly after watering and we evaluated the percent mortality and the dry weight of the plant at the end of the $28^{\text {th }}$ day.

\subsection{Data analysis}


130 After 28 days, plants in the dose-effect group were harvested and dried for 72 hours at $65^{\circ} \mathrm{C}$ to 131 obtain the dry weight of the biomass. A dose-response analysis was performed using the $\mathrm{R}$ program 132 and Log-logistic model below (Ritz et al., 2015):

$$
y=c+\frac{d-c}{1+\exp \left(b\left(\log (x)-\log \left(E D_{50}\right)\right)\right.}
$$

134

135

136

137

138

139

140

141

142

143

144

145

146

147

148

149

150

151

152

153

154

155

156

157

158

159

In these formulas, $\mathrm{Y}$ is the response, $\mathrm{d}$ is the upper limit, $\mathrm{c}$ is the lower limit, $\mathrm{b}$ is the logarithmic

(e) regression curve, and $\mathrm{ED}_{50}$ is the dosage needed to reduce mass. The resistance factor and $\mathrm{ED}_{50}$ values of the resistant populations were calculated using this formula.

\subsection{Molecular studies}

\subsubsection{DNA extraction}

Thirteen populations were found to be resistant to herbicides. Specimens from these populations were grown in the greenhouse and leaves were collected at the four-to-six leaf stage. The collected leaves were used to extract the genomic DNA with DNA extraction kit (Danquash et al., 2002).

\subsubsection{Polymerase chain reaction}

The DNA isolated from the resistant thirteen populations were used in PCR studies to amplify Trp574 residue with the ALS3F (5'-GGRGAAGCCATTCCTCC-3') and ALS3R (5'TCARTACTWAGTGCKACCATC-3') primer sets (Tan and Medd, 2002). About $25 \mu 1$ PCR reaction were prepared as follows: 10X PCR buffer, $70 \mathrm{ng}$ genomic DNA, $0.50 \mathrm{mM}$ primer, 3.5 $\mathrm{mM} \mathrm{MgCl} 2,0.9 \mathrm{mM}$ DNTP, and $1 \mathrm{U}$ Taq DNA Polymerase (Thermoscientific, Vilnius, Lithuania). The PCR program was set to: denaturation $94^{\circ} \mathrm{C} 2 \mathrm{~min}, 60^{\circ} \mathrm{C} 30 \mathrm{sec}, 72^{\circ} \mathrm{C} 1 \mathrm{~min}, 35$ cycles $94^{\circ} \mathrm{C}$ $20 \mathrm{sec}, 59^{\circ} \mathrm{C} 30 \mathrm{sec}$, and $72^{\circ} \mathrm{C} 1 \mathrm{~min}$; the melting temperature was increased $1^{\circ} \mathrm{C}$ per cycle, and was $72^{\circ} \mathrm{C} 5 \mathrm{~min}$ and $4^{\circ} \mathrm{C} 1 \mathrm{~min}$ by the end (Tan and Medd, 2002). The amplification products were separated on a $1 \%$ agarose gel in $1 \times$ TAE buffer.

\subsubsection{DNA sequencing}

PCR products were sequenced in the REFGEN laboratory (Ankara) and the obtained sequences were subjected to blast comparison with Arabidopsis thaliana L. and other ALS-resistant weeds published in NCBI database. 
160 Results

161 3.1. Results of bioassay studies

162 We screened a total of 310 populations collected from Amasya, Çorum, Tokat and Yozgat for 163 bioassay studies. Thirteen populations with less than $80 \%$ active compound controls were selected 164 as being resistant and were used in dose-response studies (Figure 2).

165

166

\subsection{Result of dose response studies}

167

168

169

170

171

172

173

174

175

176

177

178

179

180

181

182

\section{Discussion}

184

185

186

187

188

189

\subsection{Trp-574 gene region base sequence analysis}

The sequences of 13 resistant populations were compared with susceptible (X15514) Arabidopsis and susceptible wild mustard populations (AY964648). We downloaded FJ655876, FJ655877, AY964658, AY964661 and AY964663 from NCBI to determine their mutation-resistant accessions; these were used for comparison and to observe the mutation points. The presence of some nucleotide differences these base differences were not significant and only T-036 (MW252058) showed target site mutation (Trp-574-Leu) resistance.

The base difference was detected from the results of the mutation during amino acid synthesis. The order of amino acids at Trp-574 was determined to be TGG instead of TTG. Thus, we studied the transformation of the tryptophan amino acid (W) transformation to leucine (L). The sequence comparisons of resistant and susceptible populations are shown in Figure 3.

Weed infestation and competition are major factors causing reduced growth and significant yield losses for wheat production. Herbicides offer cheaper and more effective chemical control for wheat fields, however the intensive use of herbicides may increase the risk of producing resistant weeds. Herbicide resistance is expressed as the ability of weeds to stay alive after continued exposure to low doses of herbicides. Resistance has been studied in previous studies and the results determined that weed resistance emerged after regular applications of ALS-inhibiting herbicides 
190 over three to five years. (Wang et al., 2019; Powles and Yu, 2010; Tranel and Wright, 2002). We 191 investigated the ALS herbicide resistance level of wild mustard in 310 wild mustard populations; 192 only 13, including seven from Tokat, three from Yozgat, two from Amasya and one from Çorum, 193 developed resistance.

Herbicides are generally absorbed by the leaves and roots of plants and must be bound to 195 the enzyme to become active. Acetolactate synthase is one of the enzymes involved in herbicide 196 197 198 activation and this function is inhibited by herbicides including imazamox and tribenuron methyl (Shaner and O'Connor, 1991). Resistance emerges when a nucleotide difference occurs due to an amino acid point mutation at the binding site (Kolkman et al., 2004). There are 17 amino acids, to 199 date, upon which substitution in the ALS gene confers ALS-inhibitor resistance in plants, yeast, 200 bacteria, and green algae (Christoffers et al., 2006; Duggleby and Pang, 2000; Duggleby et al., 201 2008; Tranel and Wright, 2002). Although mutations in 17 amino acid have been reported in plants, 202 bacteria, yeast, and green algae, only eight amino acid positions, including Ala 122, Pro 197, Ala 203 205, Asp 376, Arg 377, Trp 574, Ser 653 and Gly 654, have been reported in weeds (Li et al., 204 2008; Yu and Powles, 2014; Poweles and Yu, 2010; Gherekhloo et al., 2018). Each amino acid 205 plays a role in the resistance of different herbicide groups. Gly654 develops resistance to IMI, SU, 206 and SCT; Pro197 is involved in the resistance to TP and SU; Ser653 induces resistance to PTB 207 and IMI; Ala122 and Ala205 cause resistance to IMI; Asp376 and Trp-574 leads to the resistance 208 in all ALS herbicide groups (Cruz-Hipolito et al., 2013). Resistance to sulfonylurea and 209 imidazolinone develop after the mutation of Trp-574 to Leu, while resistance to tribenuron-methly occurs following Trp-574 to the Gly point mutation (Warwick et al., 2005; Jian et al., 2011).

212 (Powles and Yu, 2010; Tranel et al., 2019; Zao et., al 2020). Trp-574-Leu has the ability to develop 213 resistance to all groups of ALS inhibitor herbicides (Pandolfo et al., 2016). The Trp-574 Leu 214 mutation occurs with a higher level of resistance against IMI (Imazamox) and SU (Tribenuron 215 methyl), according to various studies (Tranel and Wright, 2002; Warwick et al., 2005; Tan and 216 Medd, 2002; Rosaria et al., 2011; Christofers et al., 2006; Deng et al., 2017; Ntoanidou et al., 217 2017; Ntoanidou et al., 2019).

218 We screened 13 resistant populations for dose effect studies, and the Trp-574 amino acid 219 mutation and base differences were observed in the T-036 population collected from a wheat field 220 in Tokat that had been sprayed with imazamox, and tribenuron-methyl. The Blast results of this 
221 population indicated a nucleotide difference at the Trp-574 amino acid and showed TGG 222 transversion to TTG. Gherekhloo et al. (2018) conducted a similar study in Iran to determine the 223 cross resistance against tribenuron-methyl in wild mustard and observed base differences in the

224

225

226

227

228

229

230

231

232

233

234

235

236

237

238

239

240

241

242

243

244

245

246

247

248

249

250

251

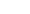

nucleotides. The base order at Trp-574 was TTG instead of TGG in AL-3, G-5, and Ag-Rs populations. Ntoanidou et al. (2017) determined the mutation of Trp-574 of nine populations after tribenuron-methyl and imazamox were applied in Greece.

Studies in Turkey to assess the resistance to ALS inhibiting herbicides were conducted at a bioassay level (Avc1, 2009; Aksoy et al., 2010; Uygur et al. 2014; Gürbüz, 2016). One study to determine the molecular detection of chlorsulfuron resistance of wild mustard was conducted but did not find the point mutation (Topuz, 2007). Kaya-Altop (2012) collected plants from paddy fields and investigated the resistance of Cyperus difformis L. against ALS inhibitors. They determined that there was a point mutation in Pro 197 amino acids. Erken (2016) screened Lolium spp. against multiple resistances and observed mutations in the Pro 197 amino acid, however, Trp574 mutations were not reported. Erken (2016) also investigated Lolium spp. against multiple resistances and only observed mutations in the Pro 197 amino acid; Trp 574 mutations were not reported.

Our study is the first to show the Trp-574 amino acid mutation in S. arvensis in wheat fields in Turkey. Our results will contribute to future studies and will assist in the selection of proper management methods.

\section{Conclusions}

In Turkey, S. arvensis with the ALS inhibitors were found to develop resistance to herbicides. The active ingredient of tribenuron-methyl used in wheat growing areas was found to have no effect on $S$. arvensis. Due to this mutation, the Leu transformation of Trp 574 occurred at the ALS enzyme, resulting in mutational resistance. Producers in the region where T-036 is grown regularly use herbicides with tribenuron-methyl and imozamox. We identified the Trp 574 mutations in the wild mustard plant for the first time in Turkey.

\section{References}


252

253

254

255

256

257

258

259

260

261

262

263

264

265

266

267

268

269

270

271

272

273

274

275

276

277

278

279

280

281

282

283

284

285

286

287

288

289

290

291

292

293

294

295

296

297

Ali A, McLaren RD, and Souza Machado V. 1986. Chloroplastic resistance to triazine herbicides in Sinapis arvensis L. (Wild mustard). Weed Res. 26:39-44.

Anonymus. 2008. Zirai Mücadele Teknik Talimatları, Cilt 6. T.C. Tarım ve Köyişleri Bakanlığı Tarımsal Araştırmalar Genel Müdürlüğü, 286s, Ankara.

Atak M. 2004. Farklı Triticale Hatlarının Morfolojik ve DNA Markörleriyle Genetik Karakterizasyonu. Ankara Üniversitesi, Fen Bilimleri Enstitüsü, Doktora Tezi. 116 sy.

Aydın N, Bayramoğlu HO, Mut Z. and Özcan H, 2005. Ekmeklik Buğday (Triticum aestivum L.) Çeşit ve Hatlarının Karadeniz Koşullarında Verim ve Kalite Özelliklerinin Belirlenmesi. AÜZF Tarım Bilimleri Dergisi, Cilt 11, Sayı 3, 257-262 Ankara.

Bülbül F. ve Aksoy E. 2005. Çukurova'da Buğday Tarlalarında Görülen Önemli Yabancı Otlar ve Mücadelesi. Bereket, 2005-1, Adana Zirai Mücadele Araştırma Enstitüsü, Adana, 2 sayfa (Çiftçi Mektubu).

Combellak JH. 1987. Weeds in Cropping Their Cost to the Australian Economy. Plant Protection Quartely 2:2.

Corbett CL. and Tardif FJ. 2006. Detection of Resistance to Acetolactate Synthase Inhibitor in Weeds with Emphasis on DNA Based Techniques. Pest Mang. Sci. 62:584-597 (2006).

Cruz-Hipolito H, Rosario J, Ioli G, Osuna M, Smeda RJ, González-Torralva F, De Prado R, (2013). Resistance Mechanism to Tribenuron-Methyl in White Mustard (Sinapis alba) from Southern Spain. Weed Science, 61(3), 341-347. doi:10.1614/WS-D-12-00146.1

Danquah ET, Johnson DE, Riches C., Arnold GM., and Karp A. 2002. Genetic Diversty in Echinocloa spp. Collected from Different Geographic Origins and Within Rice Fields in Cote'dLvoire, Weed Research. 42 (5), pp. 394-405. https://doi.org/10.1046/j.13653180.2002.00300.x

De Prado, R.A., Franco, A.R., 2004. Cross-resistance and Herbicide Metabolism in Grass Weeds in Europe: Biochemical and Physiological Aspects. Weed Sciece. 52; 441-447.

Debreuil, D.J., Friesen, L.F. and Morrison, I.N., 1996. Growth and Seed Return of Qusin Type Herbicide Resistant Wild Mustard (Brassica kaber) in Wheat. Weed Sci. 44:871-878.

Devine, MD., Shukla A.I. 2001. Altered target stes as a mechanism of herbicide resistance. Crop Protection, 19, 881-889.

FAO, 2020. Statistics on Pesticides Use in Agriculture, $1990 \quad$ - 2018. http://www.fao.org/economic/ess/environment/data/pesticides-use/en/ (25.01.2021)

Gherekhloo, J., Hatami, Z.M., Alcantara-de la Cruz, R., Sadehipour, H.R. and De Prafo, R., 2018. Continuous Use of Tribenuron-methyl Selected for Cross-Resistance to Acetolactate Synthase Inhibiting Herbicides in Wild Mustard (Sinapis arvensis). Weed Science. Volume 66, Issue 4 July 2018, pp. 424-432.

Ghorbani, R., Leifert, C., Seel, W., 2005. Biological Control of Weeds with Antagonistic Plant Pathogens. Adv. Agron. 86, 191-225.

Grassel, J., 2002. Molecular Biology of Weed Control, Taylor \& Francis, London, s. 157.

Güncan, A. ve Karaca, M., 2014. Yabancı Ot Mücadelesi (Güncelleştirilmiş ve İlaveli Üçüncü Baskı) Selçuk Üniversitesi Ziraat Fakültesi Yayınları Konya, 310s.

Güncan, A., 1972. Türkiye'de Yabanc1 Ot Problemi. Atatürk Üniversitesi, Ziraat Fakültesi Dergisi, 3: 147-152.

Heap, I., 2014. Global Perspective of Herbicide Resistant Weeds. Pest Manag. Sci., 70:1306-1315. Heap, I., 2020. http://www.weedscience.org/Home.aspx (01.02.2020).

Heap, I.M. and Morrison, I.N., 1992. Resistance to Auxin Type Herbicides in Wild Mustard (Sinapis arvensis L.) Populations in Western Canada. Weed Sci. Soc. Am. Abstr. 32-55.

Peer] reviewing PDF | (2020:11:55641:3:0:NEW 3 Apr 2021) 
298

299

300

301

302

303

304

305

306

307

308

309

310

311

312

313

314

315

316

317

318

319

320

321

322

323

324

325

326

327

328

329

330

331

332

333

334

335

336

337

338

339

340

341

342

343

Holt, I.S., 1988. Reduced, Growth, Competitiuenses and Phtosynthatic Effiency of Triazine Resistant Senecio vulgaris from California, Journal Applied Ecology, 25, 307-318.

Jabran, K., Mahajan, G., Sardana, V., Chauhan, B.S., 2015. Allelopathy for Weed Control in Agricultural Systems. Crop Prot. 72, 57-65.

Jian S, Jin-xin W, Hong-jun Z, Jun-liang L and Sheng-nan B. 2011. Study on mutations in ALS for resistance to tribenuron-methyl in Galium aparine L. Agric. Sci. China 10:86-91.

Kaya-Altop, E., Mennan, H., Işık, D., 2017. Buğday Ekim Alanlarında Sorun Olan Bifora radians Bieb. (Kokarot)'ın ALS İnhibitörü Herbisitlere Dayanıklılı̆̆ının PCR Temelli Olarak Belirlenmesi. Anadolu Tarım Bilimleri Dergisi, 32(2), 153-163. Doi: 10.7161/Omuanajas.320414.

Kolkman JM, Slabaugh MB, Bruniard JM, Berry S, Bushman BS, Olungu C, Maes N, Abratti G, Zambelli A, Miller JF, Leon A, Knapp SJ, 2004 Acetohydroxyacid synthase mutations conferring resistance to imidazolinone or sulfonylurea herbicides in sunflower. Theor Appl Genet 109:1147-1159. doi: 10.1007/s00122-004-1716-7

Mallory-Smith, C.A., Thill, D.C., Dial, M.J., 1990. Identification of Sulfonylurea Herbicide Resistant Prickly Lettuce (Lactuca serriola). Weed Technology, 4, 163-168.

Marwat, S., Usman, K., Khan, N., Khan, M., Khan, E.A., Khan, M., Rehman, A., 2013. Weeds of Wheat Crop and Their Control Strategies in Dera Ismail Khan District, Khyber Pakhtun Khwa, Pakistan. American Journal of Plant Sciences. 4. 66-76. 10.4236/ajps.2013.41011.

Morrison, I.N. and Devine, M.D., 1994. Herbicide Resistance in The Canadian Prairie Provinces; Five After the Fact. Phytoprotection 75. (Suppl.): 5-16.

Moss, S.R., Clarke, J.H., Blair, A.M., Culley, T.N., Read, M.A., Ryan, P.J. and Turner, M., 1999. The Occurrence of Herbicide Resistant Grass Weeds in The United Kingdom and A New System for Designating Resistance in Screening Assays, Proceedings of The Brighton Crop Protection Conference on Weeds Hampshire, UK, 179-184.

Ntoanidou, S, Madesis, P., Diamantids, G. and Eleftherohorinos, I., 2017. Trp574 Substitution in The Acetolactate Synthase of Sinapis arvensis confers Cross-Resistance to Tribenuronmethyl and Imazamox. Pesticide Biochemistry and Physiology. 143(2017)9-14.

Oerke, E.C. and Dehne, H.W., 2004. Safeguarding Production Losses in Major Crops and The Role of Crop Protection. Crop Prot. 23, 275-285.

Oerke, E.C., 2006. Crop Losses to Pests. Journal of Agricultural Science, 144(1):31-43.

Oerke, E.C., Dehne, H.W., Schönbeck, F. and Webber, A., 1999. Crop Production and Crop Protection. Elsevier. Oxford, Tokyo vb. p 808.

Oerke, E.C., Dehne, H.W., Schönbeck, F. and Weber, A., 1994. Crop Production and Crop Protection: Estimated Losses in Major Food and Cash Crops, Amsterdam: Elsevier.

Özer, Z., Kadıoğlu, İ., Önen, H. ve Tursun, N., 2003. Herboloji (Yabanc1 Ot Bilimi). Gaziosmanpaşa Üniversitesi, Ziraat Fakültesi Yayınları No:29, Ders Notları Serisi No:10, 579 sayfa.

Powles, S.B. and Yu, Q. 2010. Evolution in Action: Plants Resistant to Herbicides. Annu. Rev. Plant Biol. 61, 317-347. Doi: 10.1146/annurev-arplant-042809-112119

Ritz, C., Baty, F., Streibig, J.C. and Gerhard, D., 2015. Dose-response Analysis Using R. Plos One, 10(12).

Shaner DL, O’Connor SL, 1991. The imidazolinone herbicides. In: Duke SO (ed) Herbicide resistant crops. CRC Press, Boca Raton, p 289.

Sharma, A., Kumar, V., Shahzad, B., Tanveer, M., Sidhu, G.P.S., Handa, N., Kohli, S.K., Yadav, P., Bali, A.S., Parihar, R.D., Dar, O.I., Singh, K., Jasrotia, S., Bakshi, P., Ramakrishnan,

Peer) reviewing PDF | (2020:11:55641:3:0:NEW 3 Apr 2021) 
344
M., Kumar, S., Bhardwaj, R., 2019. Worldwide pesticide usage and its impacts on ecosystem. SN Applied Sicences (2019) 1:1446.

Schneider, R.P., 1985. Weed Control Technology: Needs, Development, Constraints, Proceedings 10th Conference of the Assian-Pasific Weed Science Society, Chiangmai, 1985.

Shiferaw, B., Smale, M., Braun, H.J., Duveiller, E., Reynolds, M., Muricho, G., 2013. Crops That Feed The World 10. Past Successes and Future Challenges to The Role Played by Wheat in Global Food Security. Food Secur. 5 (3), 291e317. http:// dx.doi.org/10.1007/s12571013-0263-y.

Tan, M.K. and Medd, R.W., 2002. Characterisation of The Acetolactate Synthase (ALS) Gene of Raphanus raphanistrum L. And The Molecular Assay of Mutations Associated with Herbicide Resistance. Plant Sci. 163: 195-200.

Topuz, M., 2007. Marmara Bölgesinde Buğday Tarlalarında Bulunan Sinapis arvensis L. (Yabani Hardal)'ın Sulfonylüre Grubu Herbisitlere Karşı Oluşturduğu Dayanıklılık Üzerine Araştırmalar. Ege Üniversitesi Fen Bilimleri Enstitüsü, Doktora Tezi, 202sayfa. İzmir.

Vencill, W., Nichols, R.L., Webster, T.M., Soteres, J.k., Mallory-Smith, C., Burgos, N.R., Johnson, W.G. and McClelland, M.R., 2012. Herbicide Resistance: Toward an Understanding of Resistance Developmentand the Impact of Herbicide-Resistant Crops. Weed Science 2012, Speacial, Issue:2-30.

Warwick, S.I., Sauder, C. and Beckie, H., 2005. Resistance in Canadian biotypes of Wild Mustard (Sinapis arvensis) to Acetolactate Synthase Inhibiting Herbicides. Weed Science 53; 631639. 


\section{Table 1 (on next page)}

Table 1. $\mathrm{ED}_{50}$ values and resistance index of wild mustard populations against tribenuron methyl.

$\mathrm{ED}_{50}$ values and resistance index of wild mustard populations against tribenuron methyl. 
Table 1. $E D_{50}$

\begin{tabular}{lccccc}
\hline $\begin{array}{l}\text { Population } \\
\text { Number }\end{array}$ & $\begin{array}{l}\text { Estimated } \\
\text { ED }_{\mathbf{5 0}}\end{array}$ & $\begin{array}{l}\text { Standard } \\
\text { Eror }\end{array}$ & $\begin{array}{l}\text { ED }_{\mathbf{5 0}} \\
\text { Lower } \\
\text { Limit }\end{array}$ & $\begin{array}{l}\text { ED } \\
\text { Upper } \\
\text { Limit }\end{array}$ & $\begin{array}{l}\text { Resistance } \\
\text { Factor }\end{array}$ \\
\hline A-007 & 7.157 & 0.873 & 5.986 & 8.625 & 7.2 \\
A-022 & 3.891 & 0.360 & 3.164 & 4.618 & 3.9 \\
C-017 & 6.894 & 0.621 & 5.146 & 8.011 & 6.9 \\
T-010 & 3.927 & 0.145 & 2.986 & 4.863 & 3.9 \\
T-011 & 4.251 & 0.287 & 3.881 & 4.914 & 4.3 \\
T-012 & 7.656 & 0.544 & 5.719 & 9.271 & 7.7 \\
T-034 & 1.029 & 0.102 & 0.837 & 1.405 & 1.0 \\
T-036 & 2.141 & 0.349 & 1.452 & 2.992 & 2.1 \\
T-038 & 3.213 & 0.405 & 2.067 & 4.118 & 3.2 \\
T-050 & 5.444 & 0.109 & 5.187 & 5.972 & 5.4 \\
Y-021 & 3.168 & 0.857 & 1.546 & 4.639 & 3.2 \\
Y-022 & 2.878 & 0.382 & 2.108 & 3.649 & 2.9 \\
Y-026 & 2.330 & 0.578 & 0.164 & 3.495 & 2.3 \\
\hline
\end{tabular}

$\mathrm{ED}_{50}$ : Effective dose \% 90, The susceptible population standard is taken as 1. 


\section{Figure 1}

Figure 1. Sampled areas map

Each of the blue dots indicates the points where wild mustard samples were collected. Yellow dots are resistant sample and orange dot is TRP-574 mutation population

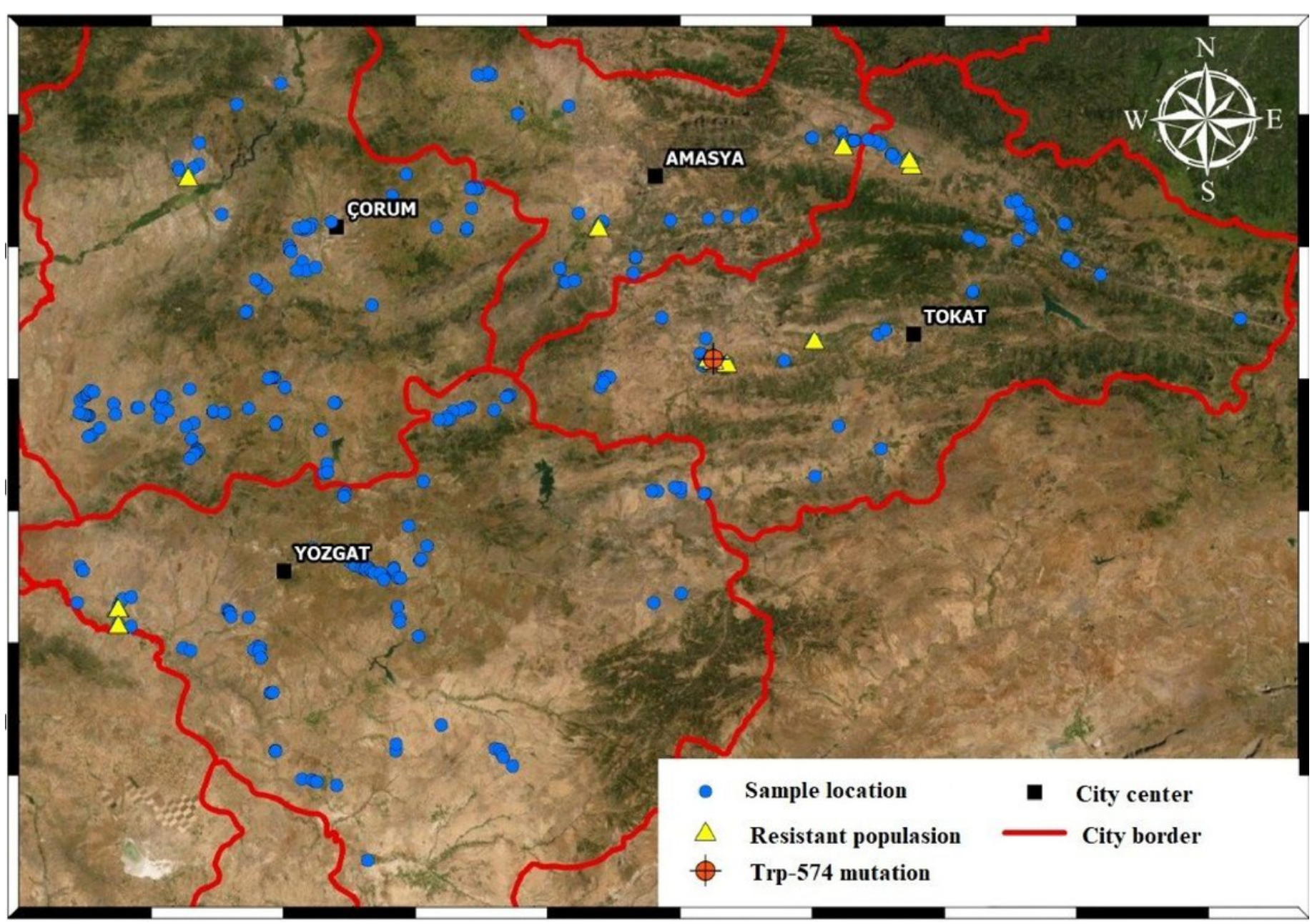




\section{Figure 2}

Figure 2.Population showing resilience as a result of bioassay study

As a result of $\mathrm{N}$ dose administration during the Bioassay study. (A) Plants treated with $\mathrm{N}$ doses, (B) Untreated control plants

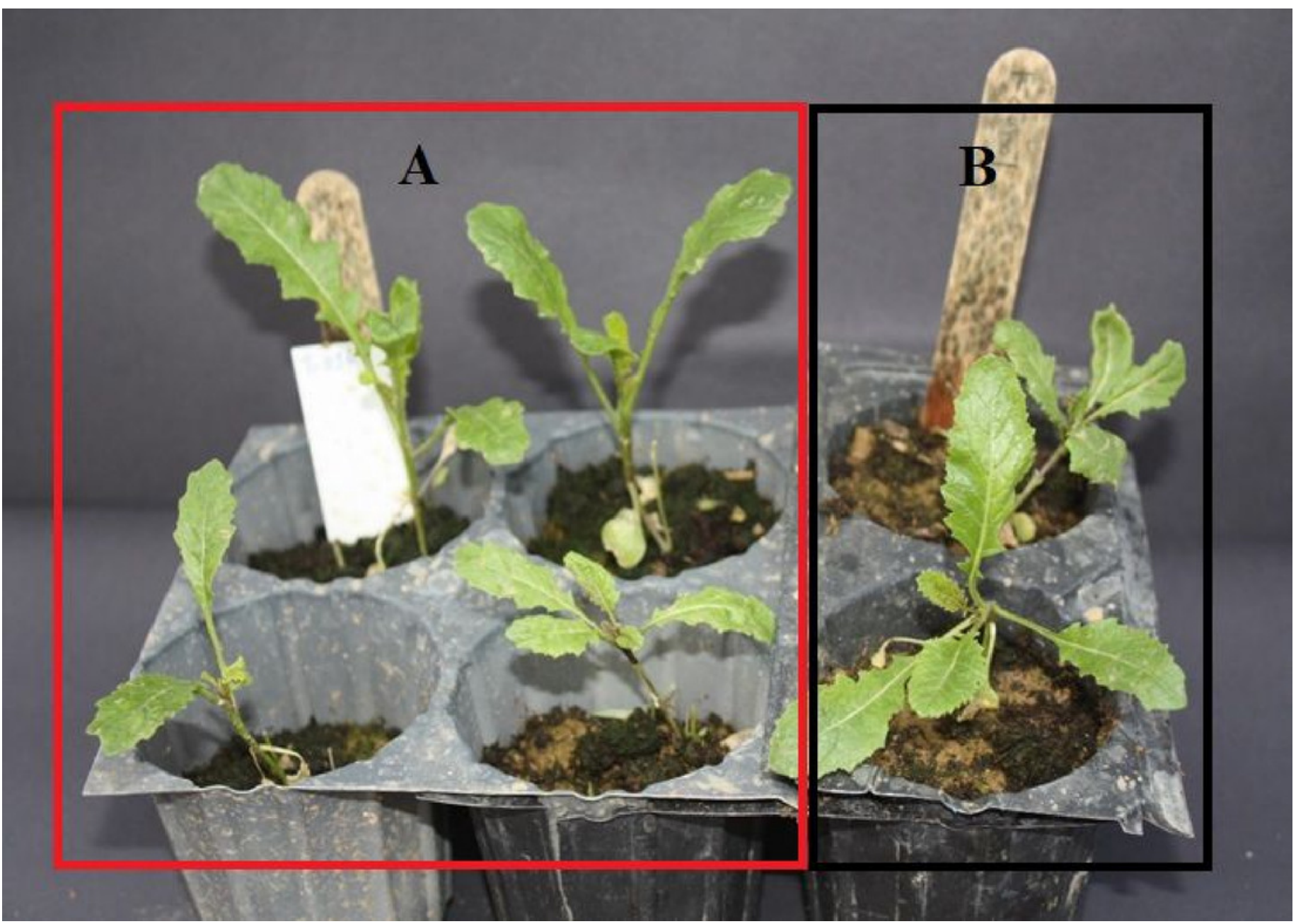




\section{Figure 3}

Figure 3. Comparison of the base sequence of resistant samples with different Sinapis arvensis samples

Nucleotide sequence of the acetolactate synthase (ALS) gene from tribenuron-methyl (TM) susceptible and TM-resistant Sinapis arvensis plants collected from winter wheat fields in TOKAT province, Turkey. Codons indicate a change at the 574 position from TGG (tryptophan=Trp) to TTG (leucine=Leu), associated with conferring cross-resistance to ALS inhibiting herbicides. 


\begin{tabular}{|c|c|c|c|c|c|c|c|c|c|}
\hline & $\begin{array}{l}570 \\
\text { Met }\end{array}$ & $\begin{array}{l}571 \\
\text { Val } \\
\end{array}$ & $\begin{array}{l}572 \\
\text { Met }\end{array}$ & $\begin{array}{l}573 \\
\text { Gln } \\
\end{array}$ & $\begin{array}{l}574^{\circ} \\
\text { Trp }\end{array}$ & $\begin{array}{l}575 \\
\text { Glu } \\
\end{array}$ & $\begin{array}{l}576 \\
\text { Asp }\end{array}$ & $\begin{array}{l}577 \\
\text { Arg } \\
\end{array}$ & $\begin{array}{l}578 \\
\text { Ser }\end{array}$ \\
\hline X51514.1 A. thaliana & ATG & GTT & ATG & CAA & TGG & GAA & GAT & CGG & TTC \\
\hline Y-021 & ATG & GTT & ATG & CAA & TGG & GAA & GAT & CGG & TTC \\
\hline T-036 & ATG & GTT & ATG & CAA & TTG & GAA & GAT & CGG & TTC \\
\hline Control & ATG & GTT & ATG & CAA & TGG & GAA & GAT & CGG & TTC \\
\hline T-003 & ATG & GTT & ATG & CAA & TGG & GAA & GAT & CGG & TTC \\
\hline $\mathrm{A}-022$ & ATG & GTT & ATG & CAA & TGG & GAA & GAT & CGG & TTC \\
\hline $\mathrm{T}-034$ & ATG & GTT & ATG & CAA & TGG & GAA & GAT & CGG & TTC \\
\hline $\mathrm{T}-010$ & ATG & GTT & ATG & CAA & TGG & GAA & GAT & CGG & TTC \\
\hline $\mathrm{T}-038$ & ATG & GTT & ATG & CAA & TGG & GAA & GAT & CGG & TTC \\
\hline Y-092 & ATG & GTT & ATG & CAA & TGG & GAA & GAT & $\mathrm{CGG}$ & TTC \\
\hline Y-026 & ATG & GTT & ATG & CAA & TGG & GAA & GAT & CGG & TTC \\
\hline $\mathrm{T}-050$ & ATG & GTT & ATG & CAA & TGG & GAA & GAT & $\mathrm{CGG}$ & TTC \\
\hline T-012 & ATG & GTT & ATG & CAA & TGG & GAA & GAT & CGG & TTC \\
\hline T-011 & ATG & GTT & ATG & CAA & TGG & GAA & GAT & $\mathrm{CGG}$ & TTC \\
\hline T-014 & ATG & GTT & ATG & CAA & TGG & GAA & GAT & CGG & TTC \\
\hline A-007 & ATG & GTT & ATG & CAA & TGG & GAA & GAT & CGG & TTC \\
\hline C-017 & ATG & GTT & ATG & CAA & TGG & GAA & GAT & $\mathrm{CGG}$ & TTC \\
\hline Y-022 & ATG & GTT & ATG & CAA & TGG & GAA & GAT & CGG & TTC \\
\hline AY964663.1_Sinapis_arvensis & ATG & GTT & ATG & CAA & TTG & GAA & GAT & CGG & TTC \\
\hline \multicolumn{10}{|l|}{ Theodore } \\
\hline AY964661.1_Sinapis_arvensis & ATG & GTT & ATG & CAA & TGG & GAA & GAT & CGG & TTC \\
\hline AY964658.1_Sinapis_arvensis & ATG & GTT & ATG & CAA & TGG & GAA & GAT & CGG & TTC \\
\hline AY964648.1_Sinapis_arvensis & ATG & GTT & ATG & CAA & TGG & GAA & GAT & CGA & TTC \\
\hline FJ655877.1_Sinapis_arvensis_MRS & ATG & GTT & ATG & CAA & TGG & GAA & GAT & CGG & TTC \\
\hline 655876.1 Sinapis arvensis K & $\mathrm{TTG}$ & GTT & & CAA & TGG & GAA & & & 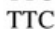 \\
\hline
\end{tabular}

Fig 3. Nucleotide sequence of the acetolactate synthase (ALS) gene from tribenuron-methyl (TM) susceptible and TM-resistant Sinapis arvensis plants collected from winter wheat fields in TOKAT province, Turkey. Codons indicate a change at the 574 position from TGG (tryptophan=Trp) to TTG (leucine=Leu), associated with conferring cross-resistance to ALS inhibiting herbicides. 